\title{
Total IgE and Absolute Eosinophils Count as a Predictor of Allergic Diseases in Children
}

\author{
* Hamid Habib, ** Moufag Tayeb, *** Majdy Qutub, **** Jamil Samkari. \\ **** Abdulrahman Abu Dawood. \\ * Consultant Pediatrician, Dean Faculty of Medicine - Rabigh - King Abdul Aziz \\ University (KAU), **Assistant Professor Faculty of Medicine - Rabigh - KAU. \\ ***Consultant Family Physician, King Abdul Aziz University Hospital. \\ ****Demonstrator Faculty of Medicine - Rabigh - KAU.
}

\begin{abstract}
Objective: To study the role of both serum total IgE levels and the absolute eosinophils count, total IgE alone, absolute eosinophils count alone as a marker of allergy in children, and to see their association with the host factors (age and sex)

Methods: A retrospective study was conducted at King Abdul Aziz University Hospital Jeddah (KAUH), during the year 2008. Three hundred children below the age of fifteen years meeting the inclusion criteria were enrolled for the study. Serum total IgE levels and absolute eosinophils count were done in all patients. Data was collected and tabulated. Chi-square was applied to test the association of the variables using SPSS and p-value of $<0.05$ was taken as statistically significant.
\end{abstract}

Results: Out of 300 patients, 27(9\%) had raised both serum total IgE and absolute eosinophils count, 146(48.67\%) had raised serum total IgE alone, 40(13.3\%) had raised absolute eosinophils count alone. Both IgE plus absolute eosinophilic count, total $\operatorname{IgE}$ alone and absolute eosinophilic count alone are not significantly related to the child sex with (P-values 0.759, $0.742,0.699)$ respectively, however all are related significantly to the child age (P-values $<0.004,<0.001,<0.012)$ respectively. All are not related significantly to systemic allergies except the significant relation between the absolute eosinophils count with atopic dermatitis ( $\mathrm{P}$ value $<0.031$ )

Conclusion: Serum total $\operatorname{IgE}$ level and absolute eosinophils count, total $\operatorname{IgE}$ alone and absolute eosinophils count alone are not a good predictor of allergy in children except that the absolute eosinophils count can be considered as a strong predictor of atopic dermatitis in children. It's clear now, that as the child age increase the positivity of all the tests increase also.

\section{Introduction}

There is growing evidence that the prevalence of allergic diseases such as asthma, hay fever and eczema is increasing worldwide (Beasley 2000. Downs 2001). Although there is greater awareness of allergy, it is not easy to assess the true prevalence because many people do not consult health professionals for their symptoms and some will self-medicate using over the counter medications (Walker et al, 2005).
It's well known that allergic diseases can be associated with each others. Rhinitis has a strong association with asthma and atopic dermatitis in preschool children (Peroni et al, 2003). Individuals with concomitant allergic rhinitis and asthma complain of a higher rate of asthma attacks and more emergency room visits than others without concomitant allergic rhinitis (Bouquet et al, 2005). 
Al Frayh et al (2001) indicated that there was a significant increase in the prevalence of bronchial asthma and, to a lesser extent, in the prevalence of allergic rhinitis in the Kingdom of Saudi Arabia. Prevalence of other childhood allergic diseases isn't clear because of the paucity of studies in this field.

Although the diagnostic value of specific IgE levels against definite allergic disease is well accepted, there are conflicting results about the predictive values of total serum $\operatorname{IgE}$ and absolute eosinophils levels in childhood allergies (Sapigni et al, 1998).

The aim of this study is to estimate the predictive value of using both total serum IgE plus absolute eosinophils levels in children against various allergic disorders, to see how useful a tool they are to indicate allergy.

\section{Patients and methods}

A retrospective study was conducted for three hundred sample size children below the age of fifteen years who presented to KAUH with the diagnosis of allergic diseases were included in the study. We looked at children who present to KAUH during the year 2008. Age and sex of each child was noted.

Registered allergic diseases were allergic rhinoconjunctivitis, asthma, atopic dermatitis, urticaria and angioedema, contact dermatitis, food allergy, drug allergy and anaphylaxis. Each allergic disorder was registered alone.

Diagnostic workup involved the total IgE and CBC with differential to look for the absolute eosinophils count were done in each child, and the results were compared with the standard ranges for age and sex (Glader, 2004). Serum total IgE levels were estimated by immunoassay (Vidal et al, 2005), while absolute eosinophils count was done using coulter machine. Any total $\mathrm{IgE}$ or absolute eosinophils count values above the normal range were considered as abnormal.

Specific allergens in these children were not studied as the aim was to determine the utility of total Serum IgE levels and the absolute eosinophils count, as a predictor of allergy in children.

Correlation coefficient was used to test the relation between total $\operatorname{IgE}$ and absolute eosinophils count while the descriptive analysis was used to clarify the relation between both total $\mathrm{IgE}$ plus eosinophils count with the clinical allergic presentations.

Results were compiled, tabulated and analyzed using Pearson's chi-square test for association between serum total IgE levels, absolute eosinophils count and clinical presentation of allergic diseases. Differences were considered to be significant at $p$ value $<0.05$. All calculations were done through SPSS (Statistical Package for Social Sciences).

\section{Results}

For the raised levels of both $\operatorname{IgE}$ plus absolute eosinophilic count, the percentage of the positive results increase with the child age with a significant relation $(\mathrm{p}<0.004)$, while there is no significant relation with the child sex $(\mathrm{p}=0.759)$, no significant association with all systemic allergies, p-values as (asthma 0.827, Allergic rhinitis 0.583, Allergic conjunctivitis 0.327 , Atopic dermatitis 0.186, Food allergy 0.888). 
Table 1: Association of host factors with serum total IgE levels and Absolute Eosinophilic count.

\begin{tabular}{|c|c|c|c|}
\hline Host factors & $\mathrm{n}=259$ & $\begin{array}{c}\text { Serum total IgE } \\
\text { levels and absolute } \\
\text { eosinophilic count } \\
\text { raised (n=27) }\end{array}$ & \multirow{2}{*}{ P-value } \\
\hline Age & \multicolumn{3}{|c|}{$<0.004^{*}$} \\
\hline $1-5$ & 115 & $6(5.2 \%)$ & \\
\hline $6-10$ & 62 & $5(8.1 \%)$ & \\
\hline $11-15$ & 82 & $16(19.5 \%)$ & \multirow{2}{*}{0.759} \\
\hline Sex & 156 & $17(10.9 \%)$ & \\
\hline Male & 103 & $10(9.7 \%)$ & \\
\hline Female & \multicolumn{3}{|c|}{}
\end{tabular}

$P$-value $<0.05$ were taken as statistically significant

Table 2: Association of Systemic allergies with serum total IgE levels and Absolute Eosinophilic count (AEC).

\begin{tabular}{|c|c|c|c|}
\hline Systemic allergy & $(n=259)$ & $\begin{array}{l}\text { High IgE \& } \\
\text { AEC }(n=27)\end{array}$ & P-value \\
\hline \multicolumn{4}{|l|}{ Bronchial asthma } \\
\hline Yes & 91 & $10(11 \%)$ & \multirow[t]{2}{*}{0.827} \\
\hline No & 168 & $17(10.1 \%)$ & \\
\hline \multicolumn{4}{|l|}{ Allergic rhinitis } \\
\hline Yes & 69 & $6(8.7 \%)$ & \multirow[t]{2}{*}{0.583} \\
\hline No & 190 & $21(11.1 \%)$ & \\
\hline \multicolumn{4}{|l|}{$\begin{array}{c}\text { Allergic } \\
\text { conjunctivitis }\end{array}$} \\
\hline Yes & 8 & 0 & \multirow[t]{2}{*}{0.327} \\
\hline No & 251 & $27(10.8 \%)$ & \\
\hline \multicolumn{4}{|l|}{ Atopic dermatitis } \\
\hline Yes & 60 & $9(15 \%)$ & \multirow[t]{2}{*}{0.186} \\
\hline No & 199 & $18(9 \%)$ & \\
\hline \multicolumn{4}{|l|}{ Food allergy } \\
\hline Yes & 21 & $2(9.5 \%)$ & \multirow[t]{2}{*}{0.888} \\
\hline No & 238 & $25(10.5 \%)$ & \\
\hline
\end{tabular}

$P$-value $<0.05$ were taken as statistically significant.

For the raised levels of IgE alone, the percentage of the positive results increase with the child age with a significant relation $(\mathrm{p}<0.001)$, while there is no significant relation with the child sex $(\mathrm{p}=0.742)$, no significant association with all systemic allergies, $\mathrm{p}$-values as (asthma 0.677, Allergic rhinitis 0.347, Allergic conjunctivitis 0.228, Atopic dermatitis 0.689, Food allergy 0.689 ). 
Table 3: Association of host factors with serum total IgE levels.

\begin{tabular}{|c|c|c|c|}
\hline Host Factors & $(\mathrm{n}=270)$ & $\begin{array}{c}\text { Serum Total IgE } \\
\text { levels } \\
\text { raised(n=146) }\end{array}$ & P-value \\
\hline Age & 120 & $50(41.7 \%)$ & \multirow{2}{*}{$<0.001^{*}$} \\
\hline $1-5$ & 68 & $40(58.8 \%)$ & \\
\hline $6-10$ & 82 & $56(68.3 \%)$ & \\
\hline $11-15$ & & & \multirow{2}{*}{0.742} \\
\hline Sex & 164 & $90(54.9 \%)$ & \\
\hline Male & 106 & $56(52.8 \%)$ & \\
\hline Female & & & \\
\hline
\end{tabular}

$P$-value $<0.05$ were taken as statistically significant.

Table 4: Association of Systemic allergies with serum total IgE levels.

\begin{tabular}{|c|c|c|c|}
\hline $\begin{array}{l}\text { Systemic allergies } \\
\text { Patients }(\mathrm{n}=270)\end{array}$ & $\begin{array}{c}\text { Total number of } \\
\text { IgE levels }(n=146)\end{array}$ & Raised serum & P-value \\
\hline \multicolumn{4}{|l|}{ Bronchial asthma } \\
\hline Yes & 95 & $53(55.8 \%)$ & \multirow[t]{2}{*}{0.677} \\
\hline No & 175 & $93(53.1 \%)$ & \\
\hline \multicolumn{4}{|l|}{ Allergic rhinitis } \\
\hline Yes & 71 & $35(49.3 \%)$ & \multirow[t]{2}{*}{0.347} \\
\hline $\mathrm{No}$ & 199 & $111(55.8 \%)$ & \\
\hline \multicolumn{4}{|l|}{$\begin{array}{c}\text { Allergic } \\
\text { conjunctivitis }\end{array}$} \\
\hline Yes & 8 & $6(75 \%)$ & \multirow[t]{2}{*}{0.228} \\
\hline No & 262 & $140(53.4 \%)$ & \\
\hline \multicolumn{4}{|l|}{ Atopic dermatitis } \\
\hline Yes & 64 & $36(56.2 \%)$ & \multirow[t]{2}{*}{0.689} \\
\hline No & 206 & $110(53.4 \%)$ & \\
\hline \multicolumn{4}{|l|}{ Food allergy } \\
\hline Yes & 22 & $11(50 \%)$ & \multirow[t]{2}{*}{0.689} \\
\hline No & 248 & $135(54.4 \%)$ & \\
\hline
\end{tabular}

$P$-value $<0.05$ were taken as statistically significant.

For the raised levels of absolute eosinophilic count alone, the percentage of the positive results increase with the child age with a significant relation $(p<0.012)$, while there is no significant relation with the child sex $(\mathrm{p}=0.699)$, a significant relation with atopic dermatitis ( $\mathrm{p}<0.031$ ) but no significant association with the other systemic allergies, $\mathrm{p}$-values as (asthma 0.449 , Allergic rhinitis 0.219, Allergic conjunctivitis 0.221, Food allergy 0.409). 
Table 5: Association of host factors with Absolute Eosinophilic count.

\begin{tabular}{|c|c|c|c|}
\hline Host Factors & $(\mathrm{n}=288)$ & $\begin{array}{c}\text { High Absolute } \\
\text { Eosinophilic count } \\
(\mathrm{n}=40)\end{array}$ & \multirow{2}{*}{ P-value } \\
\hline Age & & & \multirow{2}{*}{$<0.012^{*}$} \\
\hline $1-5$ & 131 & $11(8.4 \%)$ & \\
\hline $6-10$ & 68 & $9(13.2 \%)$ & \\
\hline $11-15$ & 89 & $20(22.5 \%)$ & \multirow{2}{*}{0.699} \\
\hline Sex & 172 & $25(14.5 \%)$ & \\
\hline Male & 116 & $15(12.9 \%)$ & \\
\hline Female & & & \\
\hline
\end{tabular}

$P$-value $<0.05$ were taken as statistically significant.

Table 6: Association of Systemic allergies with serum Absolute Eosinophilic count.

\begin{tabular}{|c|c|c|c|}
\hline $\begin{array}{l}\text { Systemic allergies } \\
\text { Patients }(n=288)\end{array}$ & $\begin{array}{c}\text { Total no of } \\
\text { eosinophilic count } \\
(n=146)\end{array}$ & High Absolute & P-value \\
\hline \multicolumn{4}{|l|}{ Bronchial asthma } \\
\hline Yes & 100 & $12(12 \%)$ & \multirow[t]{2}{*}{0.499} \\
\hline No & 188 & $28(14.9 \%)$ & \\
\hline \multicolumn{4}{|l|}{ Allergic rhinitis } \\
\hline Yes & 73 & $7(9.6 \%)$ & \multirow[t]{2}{*}{0.219} \\
\hline No & 215 & $33(15.3 \%)$ & \\
\hline \multicolumn{4}{|l|}{$\begin{array}{c}\text { Allergic } \\
\text { conjunctivitis }\end{array}$} \\
\hline Yes & 9 & $0(0 \%)$ & \multirow[t]{2}{*}{0.221} \\
\hline No & 279 & $40(14.3 \%)$ & \\
\hline \multicolumn{4}{|l|}{ Atopic dermatitis } \\
\hline Yes & 69 & $15(21.7 \%)$ & \multirow[t]{2}{*}{$<0.031 *$} \\
\hline No & 219 & $25(11.7 \%)$ & \\
\hline \multicolumn{4}{|l|}{ Food allergy } \\
\hline Yes & 26 & $5(19.2 \%)$ & \multirow[t]{2}{*}{0.409} \\
\hline No & 262 & $35(13.4 \%)$ & \\
\hline
\end{tabular}

$P$-value $<0.05$ were taken as statistically significant.

\section{Discussion:}

As the child grow up the percentage of the positive results increase for both IgE plus absolute eosinophilic count, total IgE alone and absolute eosinophilic count alone, while all are not related to the child sex nor to the systemic allergies except of the significant relation between atopic dermatitis and the absolute eosinophilic count.

The link between the environment and IgE level is well established. Infants at 9 month respond to environmental stimuli like the exposure to the local aeroallergens by the production of high levels of IgE antibodies and the persistent wheezing (Sherrill et al, 1999). Serum total IgE level is influenced by early weaning, early bottle feeding, exposure to passive smoking, pollens, cold, and pets; and is associated with blood eosinophilia (Satwani et al, 2009).

Dietary and environmental measures may influence the $\operatorname{IgE}$ response in atopy-prone children, thus confirming the role of environmental factors in the modulation of 
the phenotypic expression of atopy (Bruno et al, 1995). IgE and atopy are closely related. It has been found that the IgE level in Indian allergic patients is significantly related to atopy (Sharma et al, 2006).

Geographical location can affect total IgE levels. It has been found that the geometric mean of total serum IgE levels of Costa Rican children with either asthma or allergic rhinitis are higher than those of children with asthma or allergic rhinitis in most industrialized countries, the relationship among markers of allergy, asthma, rhinitis, and eczema in Costa Rica is similar to that found in countries with a Western lifestyle and different from that found in rural areas of Asia and Africa (Celedón et al, 2002). High levels of $\mathrm{IgE}$ found in Ethiopian children on arrival to Israel declined to Israeli control levels after several years of living in the new environment. Ethiopian children born in Israel had normal levels of IgE, suggesting that environment is the main factor affecting $\operatorname{IgE}$ levels in this population. Israeli born Ethiopian children with asthma had significantly increased serum IgE levels compared to asthmatics of Israeli origin (Iancovici et al, 2005).

Although the diagnostic value of specific IgE levels against definite allergens is well accepted, there are conflicting results about predictive value of total serum IgE Levels (Sapigni et al, 1998).

There are many studies which support the role of total $\mathrm{IgE}$ in the diagnosis of allergy in children. Serum total IgE level is a good predictor of allergy in children especially in asthmatics (Satwani et al, 2009). The highest IgE level was noted in children with combined allergic diseases (Lo et al, 1997).

But there are other studies which don't support the predictive value of total $\operatorname{IgE}$ in allergy diagnosis which shows a wide overlap of IgE levels in patients and healthy subjects, its diagnostic significance in Indian population seems to be limited (Sharma et al, 2006). The measurement of serum total $\operatorname{IgE}$ is not helpful for the diagnosis of allergic respiratory diseases because it has a quite good sensibility, a poor specificity and a poor negative predictive value. The test was more sensible and less specific in children (Fajraoui et al, 2008).

It's a logic approach to increase the predictive value of diagnosing allergies in children by doing both the total serum IgE levels plus the peripheral eosinophils counts in all cases presenting with suspected symptoms of allergies (Chowdary et al, 2003). Serum total IgE level is usually associated with blood eosinophilia (Satwani et al, 2009). IgE values and eosinophilia are markedly increased in these children under 5 years of age in Bandung, Indonesia, and the highest values are found in the 7\% with asthma (Kartasamita et al, 1994). In spite of that there are other studies about severe childhood asthma show that it may be related to a high level of total $\operatorname{IgE}$ but not to blood eosinophils counts (Siroux et al, 2003).

Skin testing was found to be the most effective measure of atopy in asthmatics more than the other tests (Khadadah et al, 2000). Total $\operatorname{IgE}$ is highly influenced by allergen skin prick test reactivity (Backer $e t$ $a l, 1992)$. Skin testing and total serum IgE measurement may be considered complementary to one another in diagnosing allergic respiratory disorders (Gharagozlou et al, 2005).

In a recent study which is considered as the first one to compare results of allergy tests according to age. This study concludes that for patients over 50 years of age the ImmunoCAP was found to be the preferred method for detecting allergy to house-dust mites and for patients less than 30 years old skin prick test is the recommended first choice (Jung et al, 2010).

In asthma, serum total $\operatorname{IgE}$ level is a strong predictor of allergy in children (Satwani et $a l, 2009)$. Serum IgE level may be used to differentiate between asthmatic and nonasthmatic individuals in conjunction with other biomarkers (Al Obaidi et al, 2008). 
IgE antibodies in blood may be beneficial not only to diagnose allergic diseases in young children but especially to serve as a marker of severity of asthma (Wickman et $a l$, 2003). In patients with severe or difficult-to-treat asthma a higher total IgE levels were observed in children and associated with asthma severity among younger patients (Borish et al, 2005).

In asthmatic children increasing atopy is associated with increasing asthma severity. However, the relationships between asthma severity and skin prick tests, and asthma severity and total serum IgE values, appear subtly different (Carroll et al, 2006).

Total serum IgE, specific IgE, airway caliber, and asthma symptoms are the main independent factors influencing the occurrence of bronchial hyperresponsiveness in a young adult (Rusznak and Davies, 1998). Airway hyperresponsiveness appears to be closely linked to an allergic diathesis, as reflected by the serum total IgE level (Sears et al, 1991).

Eosinophilia role in asthma diagnosis is contradictory. Studies which support its role in asthma show that the blood eosinophils after exercise correlate significantly with the maximal percent fall in $\mathrm{FEV}(1)$ after exercise (Lee et al, 2006), eosinophils can't be a marker for asthma in children (Oryszczyn et al, 2006). While other studies don't support its role in the persistence and severity of asthma (Siroux et al, 2003).

In allergic rhinitis total IgE levels are contradictory; however the skin prick test, specific IgE levels and eosinophils count are highly predictive (Droste et al, 1996). There is a close relationship between the skin prick test, specific $\operatorname{IgE}$ positivity and the reported symptoms of nasal allergy in a general population. Skin testing and specific $\operatorname{IgE}$ measurement may be considered complementary to one another in diagnosing allergic rhinitis (Droste et al, 1996). ${ }^{32}$ But in spite of skin test and specific serum $\operatorname{IgE}$ are correlated, they are not consistent with the results of the total serum IgE (Bañuelos et al, 2003).

But as a contradiction to the total $\operatorname{IgE}$ predictive value, another study shows that the serum total $\operatorname{IgE}$ levels increase in patients with allergic rhinitis (Pinar et al, 2005). The levels of total IgE correlate significantly with the recovery of symptoms of rhinitis in children (Choi et al, 2005).

Eosinophils count is highly predictive in rhinitis. The levels of total eosinophils count correlate significantly with the recovery of nasal eosinophils in children with symptoms of rhinitis (Choi et al, 2005). ${ }^{35}$ Nasal eosinophils count which is an organ-specific allergic inflammatory marker correlate well with the severity of rhinitis in children (Chen et al, 2006).

The data suggests that levels of total or specific IgE do not correlate with severity of chronic sinusitis in children. Nonetheless, the severity of chronic sinusitis and asthma correlate well with each other irrespective of total and specific IgE (Lin et al, 2001).

In atopic dermatitis (AD) the major predictive value is for the eosinophils count levels. Absolute eosinophils count correlates significantly with various objective clinical scores and chemokine markers $(\mathrm{AD})$, and is a useful indicator for predicting moderate to severe (AD) in children (Hon et al, 2007). Peripheral blood eosinophilia could serve as a diagnostic parameter in differentiating allergic $A D$ from non-allergic dermatitis (Jenerowicz et al, 2007).

In conclusion, both IgE plus absolute eosinophilic count, total $\operatorname{IgE}$ alone and absolute eosinophilic count alone are not significantly related to the child sex nor the systemic allergies, however all are significantly related to the child age, atopic dermatitis is related significantly to the absolute eosinophilic count. 


\section{References:}

1. Beasley R, Crane J, Lai CK, Pearce N (2000). Prevalence and etiology of asthma symptoms. Journal of Allergy and Clinical Immunology 105; S466-S472.

2. DownsSH,MarksGB,SporikR,BelosouvaEG, CarNG,PeatJK(2001). Continued increase in the prevalence of asthma and atopy. Archive of Diseases in Childhood, 84: 20-23.

3. WalkerS,SheikhA(2005).Self

reportedrhinitisisasignificantproblemfor patients with asthma. Prim Care Respir J.,14(2):83-7.

4. Peroni DG, Piacentini GL, Alfonsi L et al (2003). Rhinitis in pre-school children:prevalence, association with allergic diseases and risk factors. Clin Exp Allergy, 33 (10):1349-1354.

5. Bousquet J, Gaugris S, Kocevar V et al (2005). Increased risk of asthma attacks and emergency room visits among asthma patients with allergic rhinitis: a subgroup analysis of the improving asthma control trial. Clinical and Experimental Allergy 35; (6): 723-727.

6. Al Frayh AR, Shakoor Z, Gad El Rab MO, Hasnain SM (2001). Increased prevalence of asthma in Saudi Arabia. Ann Allergy Asthma Immunol., 86(3):292-6.

7. Sapigni T, Biavati P, Simoni M, Viegi G, Baldacci S, Carrozzi L (1998). The Po River DeltaRespiratoryEpidemiologicalSurvey:ananal ysisoffactorsrelatedto level of total serum IgE. Eur Respir J; 11: 278-83.

8. Glader B (2004). The Anemias. In: Behrman RE, Kliegman RM, Jenson HB. Nelson textbook ofpediatrics. 17thed.Philadelphia,Pennsylvania: W.B.Saunders Company; pp 1604-6.

9. Vidal, Gude , Boquete, Fernández-Merino, Meijide, J. Rey, S. Lojo, González-Quintela (2005). Evaluation of the Phadiatop test in the diagnosis of allergic sensitization in a general adult population. $\mathbf{J}$ Invest Allergol Clin Immunol; Vol. 15(2): 124-130.

10. Sherrill DL, Stein R, Halonen M, Holberg CJ, Wright A, Martinez FD (1999).Total serum $\operatorname{IgE}$ and its association with asthma symptoms and allergic sensitization among children. J Allergy Clin Immunol., 104(1):28-36.

11. Satwani H, Rehman A, Ashraf S, Hassan A (2009). Is serum total IgE levels a good predictor of allergies in children. J Pak Med Assoc., 59(10):698-702.

12. Bruno G, Cantani A, Ragno V, Milita O, Ziruolo G, Businco L (1995). Natural history of $\mathrm{IgE}$ antibodies in children at risk for atopy. Ann Allergy Asthma Immunol. , 74(5):431-6.

13. Sharma S, Kathuria PC, Gupta CK, Nordling K, Ghosh B, Singh AB (2006). Total serum immunoglobulin $\mathrm{E}$ levels in a casecontrol study in asthmatic/allergic patients, their family members, and healthy subjects from India. Clin Exp Allergy, 36(8):1019-27.

14. Celedón JC, Soto-Quiros ME, Hanson LA, Weiss ST (2002). The relationship among markers of allergy, asthma, allergic rhinitis, and eczema in Costa Rica. Pediatr Allergy Immunol., 13(2):91-7.

15. Iancovici Kidon M, Stein M, GellerBernstein C, Weisman Z, Steinberg S, Greenberg Z, Handzel ZT, Bentwich Z (2005). Serum immunoglobulin $E$ levels in IsraeliEthiopian children: environment and genetics. Isr Med Assoc J., 7(12):799-802.

16. Lo SF, Chiang BL, Hsieh KH (1997). Analysis of total IgE and allergen-specific IgE antibody levels of allergic children in Taiwan. Zhonghua Min Guo Xiao Er Ke Yi Xue Hui Za Zhi. 38: 375-80.

17. Fajraoui N, Charfi MR, Khouani H, Abouda M, Kerkenil Y, Zouari B (2008). Contribution of serum total immunoglobulin E measurement in the diagnosis of respiratory allergic diseases. Tunis Med. , 86(1):32-7.

18. V.S. Chowdary, E.C. Vinaykumar, J.J. Rao, Ratna Rao, K. Ram Babu, V. Rangamani (2003). A Study on Serum IgE and Eosinophils in Respiratory Allergy Patients. Indian J Allergy Asthma Immunol; 17(1): 21-24.

19. Kartasamita CB, Rosmayudi O, Demedts M (1994). Total serum IgE and eosinophil count in children with and without a history of asthma, wheezing, or atopy in an urban community in Indonesia. The Respiratory Disease Working Group. J Allergy Clin Immunol. , 94: 981-8.

20. Siroux V, Oryszczyn MP, Paty E, Kauffmann F, Pison C, Vervloet D, Pin I (2003). Relationships of allergic sensitization, total immunoglobulin $\mathrm{E}$ and blood eosinophils to asthma severity in children of the EGEA Study. Clin Exp Allergy, 33(6):746-51.

21. Khadadah M, Onadeko BO, Ezeamuzie CI, Mustafa HT, Marouf R, Sugathan TN (2000). The association of skin test reactivity, total serum IgE levels, and peripheral blood eosinophilia with asthma in Kuwait. J Asthma, 37(6):481-8.

22. Backer V, Ulrik CS, Wendelboe D, BachMortensen N, Hansen KK, Laursen EM, Dirksen A (1992). Distribution of serum IgE in children and adolescents aged 7 to 16 years in Copenhagen, in relation to factors of importance. Allergy; 47(5):484-9.

23. Mohammad Gharagozlou, Vahid Rastegari, Masoud Movahedi, Mostafa Moin, Mohammad Hassan Bemanian (2005). Total Serum IgE and 
Skin Tests in Children with Respiratory Allergy. Tanaffos; 4(15): 27-31.

24. Jung YG, Cho HJ, Park GY, Min JY, Kim HY, Dhong HJ, Chung SK, Kim SW (2010). Comparison of the skin-prick test and Phadia ImmunoCAP as tools to diagnose house-dust mite allergy. Am J Rhinol Allergy. 24(3):226-9. 25. Ahmad Al Obaidi AH, Mohamed Al Samarai AG, Yahya Al Samarai AK, Al Janabi JM (2008). The predictive value of $\operatorname{IgE}$ as biomarker in asthma. J Asthma. 45(8):654-63.

26. Wickman M, Ahlstedt S, Lilja G, van Hage Hamsten M (2003). Quantification of IgE antibodies simplifies the classification of allergic diseases in 4-year-old children. A report from the prospective birth cohort studyBAMSE. Pediatr Allergy Immunol; 14(6): 4417.

27. Borish L, Chipps B, Deniz Y, Gujrathi S, Zheng B, Dolan CM; TENOR Study Group (2005). Total serum IgE levels in a large cohort of patients with severe or difficult-to-treat asthma. Ann Allergy Asthma Immunol; 95(3): 247-53.

28. Carroll WD, Lenney W, Child F, Strange RC, Jones PW, Whyte MK, Primhak RA, Fryer AA (2006). Asthma severity and atopy: how clear is the relationship? Arch Dis Child; 91(5):405-9.

29. Rusznak C, Davies RJ (1998). ABC of Allergies. Diagnosing allergy. British Medical Journal; 316(7132) :686-9

30. Sears MR, Burrows B, Flannery EM, Herbison GP, Hewitt CJ, Holdaway MD (1991). Relation between airway responsiveness and serum $\operatorname{IgE}$ in children with asthma and in apparently normal children. N Engl J Med. 10; 325(15):1067-71.

31. Lee SY, Kim HB, Kim JH, Kim BS, Kang MJ, Jang SO, Hong SJ (2006). Eosinophils play a major role in the severity of exercise-induced bronchoconstriction in children with asthma. Pediatr Pulmonol; 41(12):1161-6.

32. Oryszczyn MP, Bouzigon E, Maccario J, Siroux V, Nadif R, Wright A, Kauffmann F (2007). Interrelationships of quantitative asthma-related phenotypes in the Epidemiological Study on the Genetics and Environment of Asthma, Bronchial
Hyperresponsiveness, and Atopy. J Allergy Clin Immunol; 119(1): 57-63.

33. Droste JH, Kerhof M, de Monchy JG, Schouten JP, Rijcken B (1996). Association of skin test reactivity, specific $\operatorname{IgE}$, total $\mathrm{IgE}$, and eosinophils with nasal symptoms in a community-based population study. The Dutch ECRHS Group. J Allergy Clin Immunol; 97(4): 922-32.

34. Bañuelos Arias Adel C, Montaño Velázquez BB, Campillo Navarrete MR, Mojica Martínez MD, Ayala Balboa JC, Silva Vera RI, Cisneros Salazar Mdel R, Becerril Angeles M, Ruiz Hinojosa A, Jáuregui Renaud K (2003). Skin tests, serum specific IgE and total IgE in the diagnosis of patients with perennial allergic rhinitis. Rev Alerg Mex; 50(4):147-53.

35. Pinar E, Bolat F, Oncel S, Köseoğlu M, Yüksel H, Calli C (2005). The relationship between skin test results and serum eosinophilic cationic protein, nasal eosinophilia, and total $\operatorname{IgE}$ values in patients with allergic rhinitis. Kulak Burun Bogaz Ihtis Derg; 14(5-6):101-5. 36. Choi SS, Shin KS, Hahn YS (2005). Correlation of Appearance of Nasal Eosinophils with Levels of Total Eosinophil Counts, Total $\operatorname{IgE}$, and House Dust Mite Specific IgE in Children with Symptoms of Rhinitis. Pediatr Allergy Respir Dis.; 15(1):35-43.

37. Chen ST, Sun HL, Lu KH, Lue KH, Chou MC (2006). Correlation of immunoglobulin E, eosinophil cationic protein, and eosinophil count with the severity of childhood perennial allergic rhinitis. J Microbiol Immunol Infect.; 39(3):212-8.

38. Lin YL, Huang JL, Chen LC, Wang CR (2001). Correlation of total and specific serum immunoglobulin E levels with the severity of chronic sinusitis in children. Asian Pac J Allergy Immunol.; 19(1):1-6.

39. Hon KL, Lam MC, Leung TF, Wong KY, Chow CM, Fok TF, Ng PC (2007). Are agespecific high serum IgE levels associated with worse symptomatology in children with atopic dermatitis.Int J Dermatol.; 46(12):1258-62.

40. Jenerowicz D, Czarnecka-Operacz M, Silny W (2007). Peripheral blood eosinophilia in atopic dermatitis. Acta Dermatovenerol Alp Panonica Adriat.; 16(2):47-52. 


\section{الغلوبولين المناعي هـ وعدد الحمضات المطلق كمؤشّر لتوقِّع أمراض في الاطفي الحساسية في الأطفال}

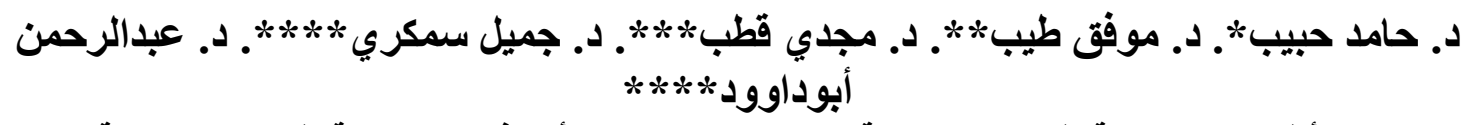

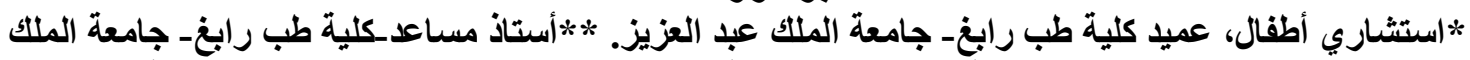

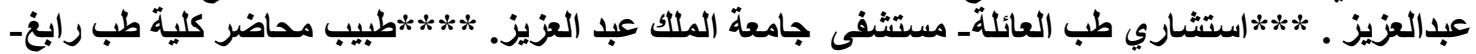
جامعة الملك عبد العزيز.

الهدف: دراسة دور كلّ من: الغلوبولين المناعي هـ في مصل الدم مع عدد الحمضات المطلق,

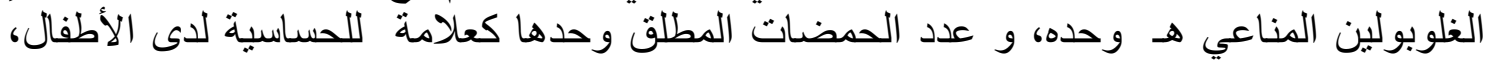
و النظر إلى ارتباطهم مع عو امل المضيف (العمر و الجنس).

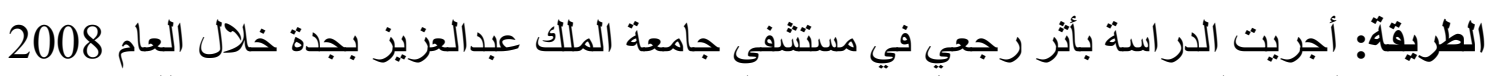

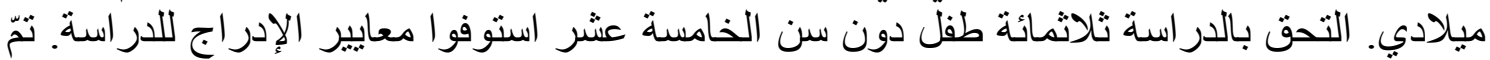

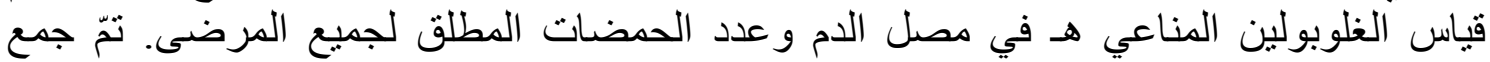

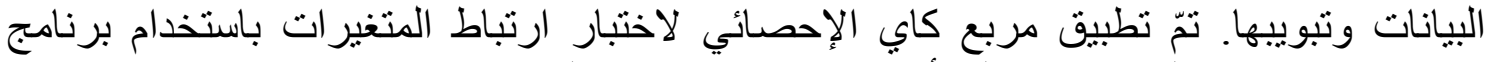
إحصائي، واعتبار القيمة الاحتمالية أصغر من 0.05 ذاتئ دالة الإنة إحصائية.

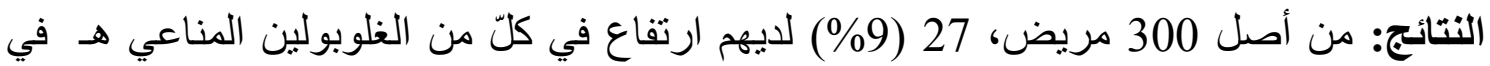

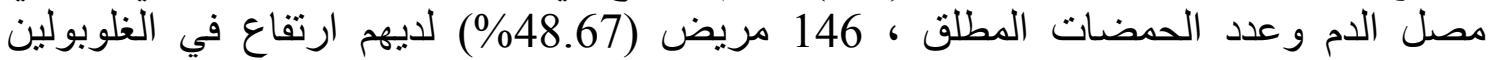

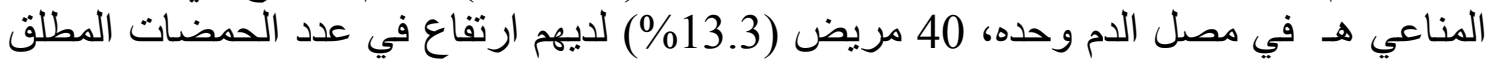

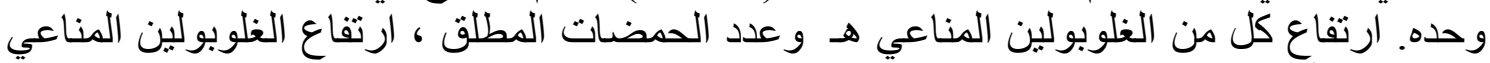

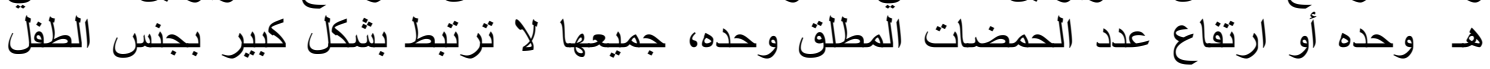

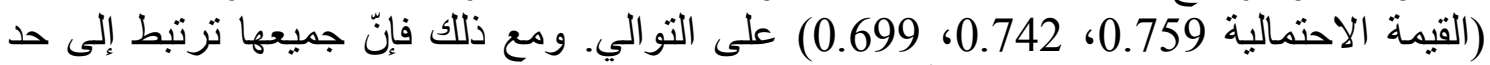

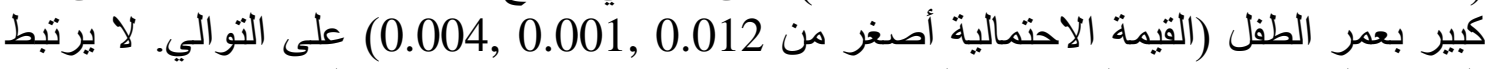

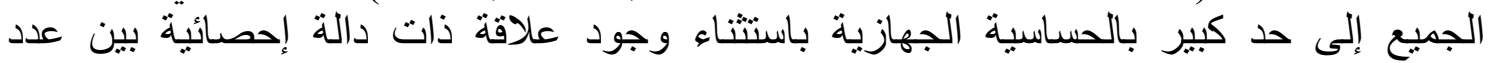

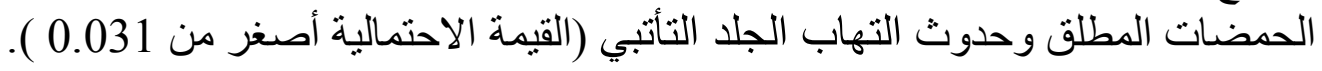

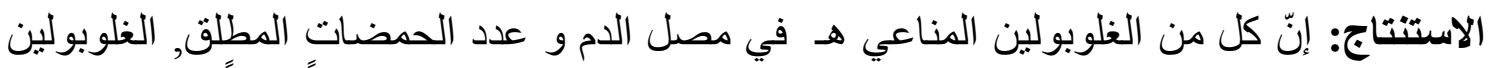

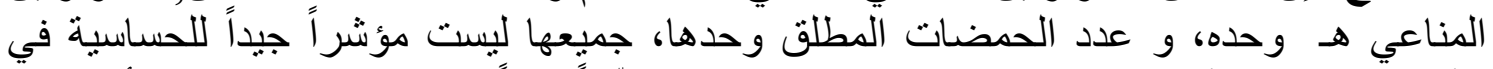

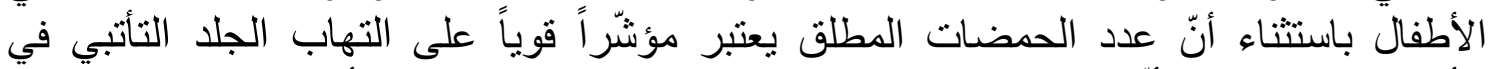

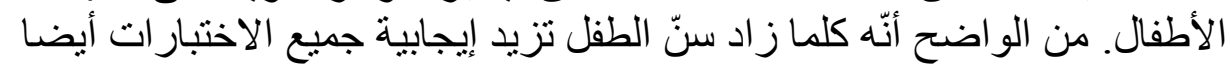

